\title{
Pengaruh Ukuran Perusahaan, Profitabilitas, Struktur Modal, Leverage dan Kepemilikan Institusional Terhadap Nilai Perusahaan
}

\author{
Hersintha Sahara ${ }^{1 *}$, Kartika Hendra Titisari ${ }^{2}$, Purnama Siddi ${ }^{3}$ \\ ${ }^{1,2,3}$ Universitas Islam Batik Surakarta \\ hersintha.sahara@gmail.com, kartikatitisari@gmail.com, purnamasiddi.1104@gmail.com
}

*Corresponding Author

Submitted: 99/xxx/9999 (mohon tidak diisi oleh author, bagian ini diisi oleh editor)

Accepted: 99/xxx/9999

Published: 99/xxx/9999

\begin{abstract}
This research aims to examine and analyze the effect of company size, profitability, capital structure, leverage \& institutional ownership on firm value in property real estate companies listed on the IDX (Indonesia Stock Exchange) from 2015-2019 period. The population obtained was 35 companies in research is property \& real estate companies listed on the IDX (Indonesia Stock Exchange) from 20152019 period \& the sample obtained was 20 companies. Sampling method used in research was "purposive sampling". This type of research is quantitative research. The type of research used in in this research is descriptive quantitative. The research data source is secondary data obtained form the annual financial statements. The data analysis used is multiple linear regression, the coefficient of determinantion test, the classical assumption test, the F test \& the hypothesis test. The results of the study showed that company size (SIZE), profitability (ROA), capital structure (DER) and leverage (DAR) affect on firm value (Price Book Value) in property and real estate companies listed on the IDX (Indonesia Stock Exchange) from 2015-2019 period, while institutional ownership (INST) not affect on firm value (Price Book Value) in property \& real estate companies listed on the IDX (Indonesia Stock Exchange) for 2015-2019 period.
\end{abstract}

Keywords: Company Zize; Profitability; Capital Structure; Leverage; Firm Value

\section{PENDAHULUAN}

Perusahaan ialah badan usaha untuk tempat perkumpulan tenaga kerja, modal, SDA dengan tujuan agar mendapatkan profit besar. Setiap manajemen mempunyai misi demi maksimumkan nilai dari company atau memakmurkan investor. Perusahaan Properti \& Real Estate dua hal berbeda, Properti adalah kepentingan dan hak-hak yang menyangkutkan subyek/ kepemilikan tanah dan bangunan sedangkan Real Estate hanya menyangkut obyek tanah dan bangunan (Fitrhi \& Asmeri, 2020). Pada era globalisasi ini keuangan memiliki peran penting dalam perusahaan. Setiap perusahaan perlu meningkatkan kinerja dan menyusun laporan keuangan dengan rinci untuk meminimalisir terjadinya kesalahan sehingga nilai perusahaan dapat tercapai. Banyak persaingan ketat antar perusahaan, oleh karena itu tingginya nilai perusahaan membantu menarik investor untuk menanamkan modal. Suatu perusahaan yang go public bertujuan untuk menyejahterakan pemegang saham \& memaksimumkan nilai perusahaan (PBV) pada harga saham (Dwita \& Kurniawan, 2019).

Research Gap (Riset Gap) yang dijadikan acuan pada penelitian ini yaitu penelitian oleh Irawan \& Kusuma (2019) menunjukkan ukuran perusahaan mempengaruhi \& signifikan terhadap company value. Sedangkan Siswanti \& Ngumar (2019) firm size tidak mempengaruhi secara signifikan pada nilai suatu perusahaan. Profitability berpengaruh pada nilai suatu perusahaan adalah ditemukan oleh (Widiyati, 2020). Sedangkan Panjaitan et al., (2020) profitability tidak mempengaruhi \& tidak signifikan pada nilai suatu perusahaan. Fitrhi \& Asmeri (2020) menyatakan capital structure berpengaruh signifikan terhadap nilai perusahaan. Sedangkan penelitian yang dilakukan oleh Febrianti \& Mufidah (2021) menyatakan bahwa struktur modal tidak memiliki pengaruh signifikan terhadap nilai suatu perusahaan. 
Marhaeningtyas \& Hartono (2020) leverage berpengaruh terhadap nilai suatu perusahaan. Lani \& Sufiyati (2019) leverage tidak memiliki pengaruh signifikan terhadap nilai suatu perusahaan. Aliyah \& Hermanto (2020) kepemilikan institusional berpengaruh terhadap nilai suatu perusahaan. Sedangkan Israel et al., (2018) menemukan kepemilikan institusional (institutional ownership) tidak memiliki pengaruh terhadap nilai suatu perusahaan.

Tabel 1. Tabel Fenomena

\begin{tabular}{|l|r|r|r|r|r|r|r|}
\hline $\begin{array}{c}\text { Kode } \\
\text { Emitmen }\end{array}$ & Thn & Total Aset & Laba Bersih & Total Ekuitas & Total Hutang & $\begin{array}{r}\text { Harga saham } \\
\text { Institusi }\end{array}$ & PBV \\
\hline APLN & 2015 & $24,559,175$ & $1,116,763$ & $9,072,669$ & $15,486,506$ & $15,811,483$ & 754.717 \\
\hline & 2016 & $25,711,953$ & 939,737 & $9,970,763$ & $15,741,191$ & $15,789,694$ & 431.781 \\
\hline & 2017 & $28,790,116$ & $1,882,581$ & $11,496,978$ & $17,293,138$ & $14,715,780$ & 353.707 \\
\hline & 2018 & $29,583,830$ & 193,730 & $12,207,553$ & $17,376,276$ & $14,715,780$ & 241.114 \\
\hline & 2019 & $29,460,345$ & 120,812 & $12,835,946$ & $16,624,399$ & $15,572,222$ & 267.026 \\
\hline ASRI & 2015 & $18,709,870$ & 684,288 & $6,602,410$ & $12,107,460$ & $10,115,790$ & 1020.801 \\
\hline & 2016 & $20,186,131$ & 510,243 & $7,187,845$ & $12,998,286$ & $8,624,103$ & 962.262 \\
\hline & 2017 & $20,728,430$ & $1,385,189$ & $8,572,692$ & $12,155,739$ & $9,284,759$ & 815.985 \\
\hline & 2018 & $20,890,926$ & 970,587 & $9,551,357$ & $11,339,568$ & $9,272,147$ & 641.858 \\
\hline & 2019 & $21,894,272$ & $1,012,947$ & $10,562,220$ & $11,332,052$ & $9,137,447$ & 442.763 \\
\hline BAPA & 2015 & $175,743,602$ & $1,204,643$ & $100,931,151$ & $74,812,451$ & 508,843 & 0.328 \\
\hline & 2016 & $179,260,878$ & $1,818,062$ & $107,220,275$ & $72,040,603$ & 508,843 & 0.309 \\
\hline & 2017 & $179,035,974$ & $13,212,382$ & $120,150,545$ & $58,885,429$ & 344,620 & 0.485 \\
\hline & 2018 & $172,313,438$ & $4,950,263$ & $127,890,305$ & $44,423,132$ & 595,067 & 0.564 \\
\hline & 2019 & $143,136,437$ & $4,956,231$ & $135,610,388$ & $7,526,049$ & 497,212 & 0.346 \\
\hline BEST & 2015 & $4,631,315,439$ & $211,935,909$ & $3,042,155,273$ & $1,589,160,167$ & $5,608,354$ & 0.932 \\
\hline & 2016 & $5,205,373,117$ & $336,287,879$ & $3,390,835,762$ & $1,814,537,355$ & $5,608,354$ & 0.723 \\
\hline & 2017 & $5,719,001,000$ & $483,387,487$ & $3,848,185,561$ & $1,870,815,438$ & $5,608,354$ & 0.627 \\
\hline & 2018 & $6,290,126,551$ & $422,536,949$ & $4,171,994,245$ & $2,118,132,307$ & $6,205,520$ & 0.481 \\
\hline & 2019 & $6,399,477,524$ & $380,152,937$ & $4,468,749,285$ & $1,930,728,239$ & $6,188,140$ & 0.466 \\
\hline BKSL & 2015 & $11,145,896,810$ & $61,673,665$ & $6,549,719,346$ & $4,596,177,464$ & $16,589,478$ & 0.306 \\
\hline & 2016 & $11,359,506,311$ & $562,426,910$ & $7,160,248,908$ & $4,199,257,403$ & $14,599,478$ & 0.444 \\
\hline & 2017 & $14,977,041,121$ & $468,559,182$ & $9,942,554,632$ & $5,034,486,489$ & $23,513,478$ & 0.723 \\
\hline & 2018 & $16,252,732,184$ & $368,591,316$ & $10,621,125,569$ & $5,631,606,615$ & $23,513,478$ & 0.567 \\
\hline & 2019 & $17,275,272,609$ & $68,928,077$ & $10,696,922,809$ & $6,578,349,800$ & $23,513,478$ & 0.439 \\
\hline
\end{tabular}

Sumber: www.idx.co.id

Tabel 1 diatas meliputi, PT APLN menunjukkan firm size pada total aset mengalami kenaikan dari tahun 2015-2016 sebesar 1,152,778 namun nilai perusahaan (PBV) mengalami penurunan sebesar 322,936. Pada PT ASRI menunjukkan laba bersih mengalami kenaikan tahun 2016-2017 sebesar 874,946 namun nilai perusahaan (PBV) mengalami penurunan sebesar 146,277. PT BAPA menunjukkan total ekuitas mengalami kenaikan dari tahun 2017-2018 sebesar 7,739,760 namun nilai perusahaan (PBV) mengalami kenaikan sebesar 0,079. PT BEST menunjukkan total hutang mengalami mengalami kenaikan dari tahun 2017-2018 sebesar 247,316,869 namun nilai perusahaan (PBV) mengalami penurunan sebesar 0,146. Pada PT BKSL menunjukkan harga saham institusi stabil dari tahun 2018-2019 sebesar 23,513,478 namun nilai perusahaan (PBV) mengalami penurunan sebesar 0,128. Disimpulkan bahwa semakin tinggi total aset maka tingkat firm value pada perusahaan properti \& real estate akan mengalami penurunan, semakin tinggi laba bersih maka firm value semakin menurun, semakin tinggi total ekuitas maka nilai perusahaan semakin meningkat, semakin tinggi total hutang maka nilai perusahaan semakin menurun, dan stabilnya harga saham institusi maka mengalami penurunan pada nilai perusahanan. 


\section{Penelitian Terdahulu}

\section{Firm Size dan nilai perusahaan}

Penelitian tentang firm size yang tinggi mempunyai kemampuan untuk meningkatkan nilai bagi perusahaan. Penelitian Al-Slehat (2020) dengan sampel 13 perusahaan di Bursa Efek Amman periode 2010-2018. Hasilnya menunjukkan firm size mempunyai pengaruh pada firm value diukur menggunakan tobin's q.

Ukuran perusahaan mampu meningkatkan nilai perusahaan juga ditemukan oleh Irawan \& Kusuma (2019) dengan sampel 39 sampel perusahaan perusahaan Manufaktur yang di BEI Periode 2014-2016. Hasil dari penelitian menunjukkan bahwa besar atau kecilnya pada firm size memiliki pengaruh pada nilai suatu perusahaan.

Firm Size yang besar kadang-kadang tidak diiringi peningkatan nilai perusahaanya ditemukan Marhaeningtyas \& Hartono (2020) dengan sampel 16 perusahaan sektor pertambangan periode 2015-2018. Hasil penelitian menunjukkan perusahaan tidak memerlukan penambahan jumlah aktiva untuk dapat mengalami peningkatan pada nilai perusahaan, maka dari itu investor perlu evaluasi terhadap company berdasar pada tinjauan secara keseluruhan atas beberapa perspektif di perusahaan meliputi tingkat penjualan \& laporan keuangan perusahaan. Hipotesis dirumuskan meliputi:

\section{H1: Firm Size berpengaruh terhadap nilai perusahaan.}

\section{Profitability dan nilai perusahaan}

Aggarwal \& Padhan (2017) dengan jumlah sampel sebanyak 22 perusahaan hotel India di Bombay Stock Exchange (BSE) periode 2001-2015. Dari peneliti menghasilkan bahwa profitability mempengaruhi pada perusahaan hotel india dalam meningkatkan nilai suatu perusahaan.

Sama halnya dilakukan oleh Siswanti \& Ngumar (2019) dengan sampel 30 perusahaan food and beverage yang terdaftar di BEI Periode 2015-2017. Hasilnya adalah perusahaan menunjukkan semakin baik peluang pada kemajuan profitability pada perusahaan sehingga semakin baik juga peluang untuk perusahaan dimasa datang. Sehingga suatu company value dianggap memiliki peluang semakin baik oleh pihak investor.

Sebagaimana Panjaitan et al., (2020) dengan banyaknya sampel 23 perusahaan goods \& consumer sector di BEI Periode 2015-2018. Peneliti menghasilkan likuiditas (CR) \& profitabilitas (ROA) tidak berpengaruh terhadap nilai suatu perusahaan, sedangkan leverage (DAR) berpengaruh terhadap nilai suatu perusahaan. Hipotesis dirumuskan sebagai meliputi:

\section{H2: Profitability (ROA) berpengaruh terhadap nilai perusahaan.}

\section{Struktur modal dan nilai perusahaan}

Fitrhi \& Asmeri (2020) dengan banyaknya sampel 28 Property \& Real Estate company di BEI 2014-2016. Hasilnya dari penelitian yakni perusahaan yang memiliki utang jangka panjang atau pendek akan mempunyai kesempatan agar memanfaatkan modalnya berkembang dengan tepat dan memberi profit bagi perusahaan \& investor sampai perusahaan memiliki kemampuan dalam manfaat \& biaya yang ada dari penggunaan hutang maka dari itu akan berpengaruh meningkatkan pada nilai suatu perusahaan.

Disamping itu Ayuba et al., (2019) yang meneliti dengan sebanyak sampel 27 perusahaan asuransi di Nigeria Stock Exchange (NSE) pada periode 2012-2017. Penelitian menghasilkan kinerja keuangan, struktur modal dan ukuran perusahaan berpengaruh pada company value.

Berbeda dengan penelitian oleh Febrianti \& Mufidah (2021) dengan populasi perusahaan industri farmasi di BEI periode 2015-2019. Hal ini penelitian jumlah sampel digunakan sebanyak 7 perusahaan. Hasil penelitian menunjukkan bahwa penambahan hutang dapat menyebabkan peningkatan resiko atas pendapatan perusahaan dari pihak eksternal. Pada nilai hutang yang tinggi, maka tinggi pula bunga hutang. Struktur modal perusahaan dengan memiliki hutang dengan jumlah yang banyak maka dari itu menyebabkan turunnya harga saham sampai dapat menurunkan nilai suatu perusahaan. Hipotesis dirumuskan meliputi:

H3: Struktur modal (DER) berpengaruh terhadap nilai perusahaan. 


\section{Leverage dan nilai perusahaan}

Dutta et al., (2018) meneliti 31 sampel perusahaan dipilih berdasarkan metode purposive sampling dari enam sektor yang berbeda yaitu sektor barang konsumsi, sektor energy, sektor industry manufaktur, sektor otomotif, sektor farmasi dan sektor jasa keuangan pada New York Stock Exchange selama 10 tahun. Hasilnya ialah leverage (DAR) mempengaruhi terhadap nilai suatu perusahaan sedang SIZE tidak berpengaruh terhadap nilai suatu perusahaan.

Widiyati (2020) meneliti 17 sampel perusahaan pertambangan batu bara di BEI periode 2017-2018. Hasil dari penelitian bahwa profitabilitas (ROA), ukuran perusahaan (SIZE), leverage (DER) mampu mempengaruhi pada nilai suatu perusahaan, cash on hand tidak mampu mempengaruhi pada nilai suatu perusahaan.

Namun Lani \& Sufiyati (2019) meneliti manufaktur sector industry \& consumen di BEI dengan tahun penelitian 2015-2017. Dengan sampel 25 perusahaan. Hasilnya adalah ukuran perusahaan (SIZE) \& leverage (DER) tidak berpengaruh pada firm value, sedangkan profitability (ROE) \& kepemilikan institusional (INST) berpengaruh pada firm value. Hipotesis dirumuskan sebagai berikut:

\section{H4: Leverage (DAR) berpengaruh terhadap nilai perusahaan.}

\section{Institutional Ownership dan nilai perusahaan}

Penelitian di Negeria oleh Oyedokun et al., (2020) dengan sampel 19 perusahaan Consumers Goods di Nigeria Stock Exchange (NSE) tahun 2010-2018. Hasil dari penelitian kepemilikan institusional (INSTO) mampu mempengaruhi terhadap nilai suatu perusahaan, kepemilikan manajerial (MGRLO), kepemilikan asing (FORNO) \& konsentrasi kepemilikan (OWC) tidak mampu berpengaruh terhadap nilai perusahaan.

Untuk itu penelitian Aliyah \& Hermanto (2020) menemukan bahwa kemampuan dalam mendorong kinerja manajemen cukup efektif untuk mempengaruhi pengambilan keputusan dan dapat melakukan pengendalian terhadap pihak manajemen melalui proses monitoring. Sehingga dapat dikatakan kepemilikan institusional mempunyai pengaruh terhadap nilai perusahaan, dapat dilihat dari pihak institusionalnya mayoritas adalah para pemegang saham. Penelitian ini 225 perusahaan LQ-45 di BEI selama tahun 2014-2018.

Namun penelitian Israel et al., (2018) dengan sampel 10 firm sektor pertambangan di BEI 2012-2016. Hasil dari penelitian institutional ownership tidak memiliki pengaruh pada company value, dikarenakan pada company dipengaruhi pihak-pihak, berkepentingan, yakni keikutsertaan dari pemerintah. Dengan begitu, pertimbangan pemilik institusional harus dilandasi banyak peraturan. Hipotesis dirumuskan sebagai berikut:

\section{H5: Intitutional Ownership (INST) berpengaruh terhadap nilai perusahaan.}

\section{Variabel Penelitian}

1. Firm Value, atau variabel dependen

Variabel dependen terdapat pada peneliti ini yaitu firm value. Definisi "firm value" adalah suatu gambaran atas pencapaian firm, jika firm value meningkat \& dapat memakmurkan investor. Firm value dapat diproksikan dengan PBV. "Price Book Value" yaitu suatu per-bandingan antara "harga saham per lembar saham" \& "nilai buku per lembar saham” (Brigham \& Houston, 2011).

$$
\mathrm{PBV}=\frac{\text { Harga Saham }}{\text { Nilai Buku }}
$$

2. Variabel Independen

\section{a. Ukuran Perusahaan}

Dalam menentukan ukuran perusahaan didasarkan kepada total aset suatu perusahaan (Permatasari \& Khuzaini, 2018). Untuk penghitungan firm size dengan melihat nilai aktiva pada perusahaan properti \& real estate. Rumus dari variabel ukuran perusahaan dapat diproksikan meliputi: 


$$
\text { Size }=\operatorname{Ln}(\text { Total Aset })
$$

b. Profitabilitas

Profitabilitas dalam penelitian Dewi \& Damayanti (2019) bahwa profitabilitas dari laba yang diperoleh perusahaan dari penjualan, total aktiva \& modal sendiri. Variabel profitability dapat diukur dengan (ROA). ROA yaitu kemampuan yang dimiliki perusahaan dengan mempergunakan dari keseluruhan aktiva \& laba bersih setelah pajak. Rumus dari variabel profitabilitas dapat diproksikan meliputi:

$$
R O A=\frac{\text { Laba Bersih Setelah Pajak }}{\text { Total Aset }}
$$

c. Struktur Modal

Rasio DER untuk menghitung total hutang dengan total ekuitas Zahiroh \& Prijati (2018) ratio ini diperlukan guna mengetahui tentang total biaya yang telah disiapkan oleh peminjam ke pihak pemilik perusahaan. Rumus dari variabel struktur modal dapat diproksikan sebagai berikut:

d. Leverage

$$
D E R=\frac{\text { Total Hutang }}{\text { Total Equitas }}
$$

Menurut Astakoni \& Wardita (2020) rasio leverage yaitu tingkat dimana kemampuan perusahaan dalam penggunaan aktiva memiliki beban tetap (debt atau saham istimewa) guna mencapai kekayaan oleh pihak pemilik perusahaan.

Rumus dari variabel leverage dapat diproksikan meliputi:

e. Kepemilikan Institusional

$$
D A R=\frac{\text { Total Hutang }}{\text { Total Aset }}
$$

Menurut Tubagus \& Khuzaini (2020) institutional ownership ialah tingkat dimana kepemilikan saham dari pihak institusi perusahaan, diproksikan oleh porposi saham oleh lembaga dengan persentase kepemilikan yang diperhitungkan pada akhir tahun pada laporan keuangan. Rumus dari variabel kepemilikan institusional dapat diproksikan sebagai berikut:

$$
I N S T=\frac{\text { Total Saham Institusi }}{\text { Total Saham Beredar }}
$$

\section{Kerangka Konseptual Penelitian}

Didapatkan gambar kerangka konseptual penelitian meliputi: 
Owner: Riset \& Jurnal Akuntansi

e-ISSN : 2548-9224 |p-ISSN : 2548-7507

Volume 6 Nomor 1, Januari 2022

DOI : https://doi.org/10.33395/owner.v6i1.580

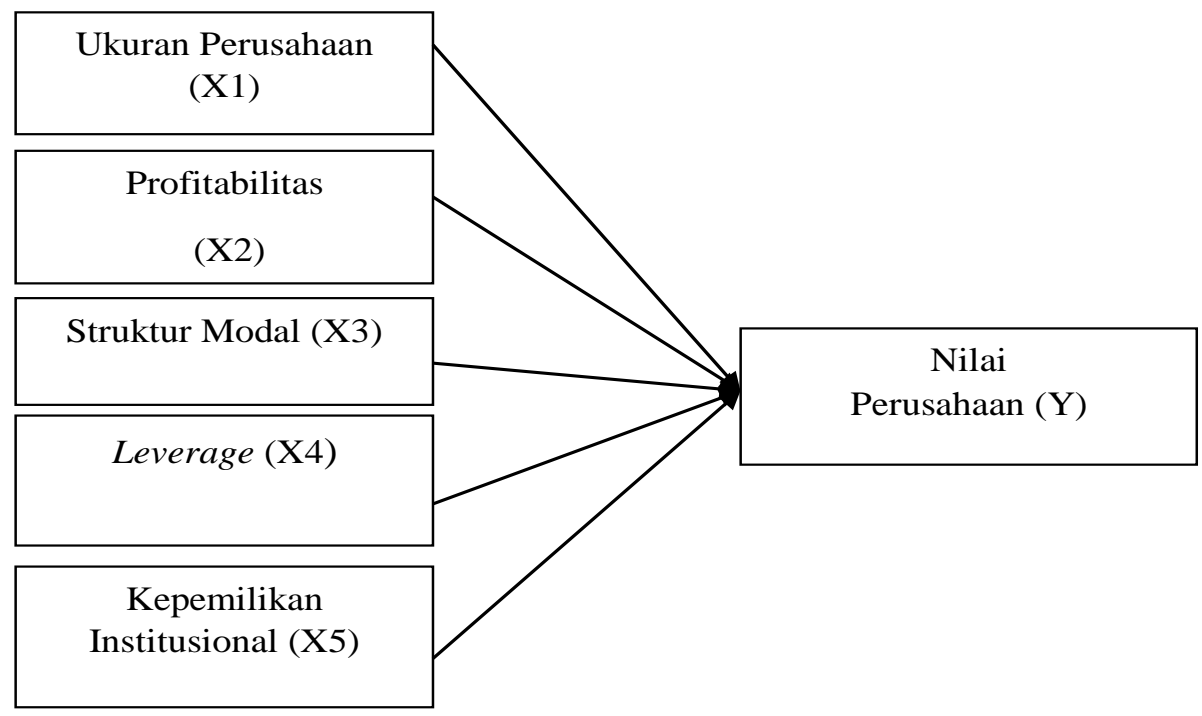

Gambar 1. Kerangka Konseptual Penelitian

\section{METODE}

Pada perusahaan property \& real estate di BEI tahun 2015-2019 didokumentasikan dalam www.idx.com. Metode penelitian ini adalah kuantitatif dan teknik analisisnya adalah statistik deskriptif dan regresi linear berganda. Populasi perusahaan properti dan real estate yaitu 35 company. Metode purposive sampling dipergunakan untuk meneliti. Terdapat sampel sebanyak 20 perusahaan properti \& real estate, dengan pengambilan sampel sebanyak 5 tahun. Kriteria pengambilan sampel meliputi :

Tabel 2. Kriteria Pengambilan Sampel

\begin{tabular}{lc}
\hline Kriteria & Jumlah \\
\hline Perusahaan Properti \& Real Estate yang terdaftar berturut-turut di BEI & 35 \\
tahun ,2015-2019 & 12 \\
Perusahaan Properti \& Real Estate memiliki data tidak lengkap & 3 \\
Perusahaan yang tidak laba & $(0)$ \\
Perusahaan Properti \& Real Estate tidak menyajikan mata uang rupiah & $\mathbf{2 0}$ \\
Jumlah Sampel Perusahaan & 100 \\
Jumlah Sampel Penelitian 5 tahun x 20 & 12 \\
Outlier & $\mathbf{8 8}$ \\
Total observasi penelitian & \\
\hline
\end{tabular}

\section{Model Penelitian}

Analisis data yang dipergunakan untuk meneliti ialah regresi linear berganda dan mempergunakan program SPSS.

$\mathrm{Y}=\alpha+\beta 1 \mathrm{X} 1+\beta 2 \mathrm{X} 2+\beta 3 \mathrm{X} 3+\beta 4 \mathrm{X} 4+\beta 5 \mathrm{X} 5+€$

Keterangan:

$\mathrm{Y}=$ Nilai Perusahaan (PBV)

$\alpha=$ konstanta

$\beta 1, \beta 2, \beta 3, \beta 4, \beta 5=$ koefisien regresi

$\mathrm{X} 1=$ Ukuran Perusahaan (Size)

$\mathrm{X} 2=$ Profitabilitas $(\mathrm{ROA})$

X3 $=$ Struktur modal (DER)

$\mathrm{X} 4=$ Leverage $(\mathrm{DAR})$

X5 $=$ Kepemilikan Institusional (INST) 
$€=$ Error

HASIL

Statistik Deskriptif dalam pengujian ini bahwa data minimum \& maksimum serta mean dari variabel independen dan dependen.

Tabel 3. Uji Statistik Diskriptif Descriptive Statistics

\begin{tabular}{lrrrrr}
\hline & N & \multicolumn{1}{c}{ Min } & \multicolumn{1}{c}{ Max } & \multicolumn{1}{c}{ Mean } & \multicolumn{1}{c}{ Std. Deviation } \\
\hline Ukuran Perusahaan & 88 & 15.10 & 24.31 & 20.4157 & 3.01014 \\
Profitabilitas & 88 & .00 & .14 & .0496 & .03282 \\
Struktur Modal & 88 & .04 & 3.70 & .8528 & .66082 \\
Leverage & 88 & .04 & .79 & .4003 & .18671 \\
Kepemilikan & 88 & .31 & .95 & .6142 & .17038 \\
Institusional & & & & & \\
Nilai Perusahaan & 88 & .16 & 12769.62 & 574.8567 & 1681.29887 \\
Valid N (listwise) & 88 & & & & \\
\hline
\end{tabular}

Tabel 3 diatas menjelaskan sebagai berikut:

Ukuran Perusahaan minimumnya pada perusahaan properti dan real estate sejumlah 15,10 dan maksimum 24,31, mean 20,4157 serta standar deviasi sebesar 3,01014 dengan $\mathrm{N}$ sebanyak 88. Profitabilitas minimumnya pada perusahaan properti dan real estate sejumlah 0,00 dan maksimum 0,14, mean 0,0496 serta standar deviasi sebesar 0,03282 dengan N sebanyak 88 . Capital Structure minimumnya pada property \& real estate company sejumlah 0,04 dan maksimum 3,70, mean 0,8526 serta standar deviasi sebesar 0,66082 dengan $\mathrm{N}$ sebanyak 88 . Leverage minimumnya pada perusahaan properti dan real estate sejumlah 0,04 dan maksimum 0,79 , mean 0,4003 serta standar deviasi sebesar 0,18671 dengan $\mathrm{N}$ sebanyak 88 . Kepemilikan Institusional minimumnya pada perusahaan properti dan real estate sejumlah 0,31 dan maksimum 0,95, mean 0,6142 serta standar deviasi 0,17038 dengan $\mathrm{N}$ sebanyak 88 . Nilai Perusahaan minimumnya pada perusahaan properti \& real estate sejumlah 0,16 \& maksimum 12769,62 , mean serta 574,8567 standar deviasi 1681,29887.

\section{Hasil Uji Asumsi Klasik}

Pada penelitian ini melakukan pengujian dengan variabel firm value, profitability, struktur modal (DER), leverage \& institutional ownership terhadap nilai firm value. Uraian dari, "uji asumsi klasik" meliputi:

Tabel 4. Uji Normalitas Kolmogorov-Smirnov

\begin{tabular}{llr}
\hline & & $\begin{array}{c}\text { Unstandardized } \\
\text { Residual }\end{array}$ \\
\hline $\mathrm{N}$ & & 88 \\
Normal Parameters & & .0000000 \\
& Mean & 830.45960067 \\
Most Extreme Differences & Std. Deviation & .083 \\
& Absolute & .083 \\
& Positive & -.073 \\
Kolmogorov-Smirnov Z & Negative & .776 \\
Asymp. Sig. (2-tailed) & & .584 \\
\hline
\end{tabular}

Hasil pengujian tersebut yakni 0,584 menunjukkan bahwa data model regresi mempunyai data terdistribusi normal. 
Owner: Riset \& Jurnal Akuntansi

e-ISSN : 2548-9224 |p-ISSN : 2548-7507

Volume 6 Nomor 1, Januari 2022

DOI : https://doi.org/10.33395/owner.v6i1.580

Tabel 5. Hasil Uji Multikolinearitas

\begin{tabular}{llrr}
\hline Model & \multicolumn{2}{c}{ Collinearity Statistics } \\
& Tolerance & VIF \\
\hline 1 (Constant) & & \\
Ukuran Perusahaan & .683 & 1.463 \\
Profitabilitas & .764 & 1.309 \\
Struktur Modal & .141 & 7.073 \\
Leverage & .113 & 8.888 \\
Kepemilikan Institusional & .527 & 1.897 \\
\hline
\end{tabular}

Tolerance \& VIF ialah $>0,10 \&<10$ dengan begitu variabel firm size, profitability, struktur modal (DER), leverage \& kepemilikan institusional tidak mengalami masalah multikolinearitas.

\section{Hasil Uji Autokorelasi}

Teknik digunakan menguji autokorelasi guna mengetahui ada / tidaknya korelasi pada model ini yaitu dengan metode durbin Watson (Cochrane orcutt).

Tabel 6. Hasil Uji Autokorelasi (Cochrane Orcutt)

\begin{tabular}{lrrrrr}
\hline Model & R & R Square & $\begin{array}{c}\text { Adjusted R } \\
\text { Square }\end{array}$ & $\begin{array}{c}\text { Std. Error of the } \\
\text { Estimate }\end{array}$ & Durbin-Watson \\
\hline 1 & $.897^{\text {a }}$ & .804 & .792 & 655.95434 & 1.848 \\
\hline
\end{tabular}

Berdasarkan tabel 6 menunjukkan bahwa perolehan hasil statistik DW, pengolahan data dengan metode Cochrane Orcutt sebesar 1,848 \& tabel DW $(\mathrm{k}=5)$ dan $\mathrm{N}=87$ besar nilai $\mathrm{dL}=$ 1,5356 dan dU = 1,7749; 4-dU=2,226. Syarat untuk DW yakni "DU < Durbin Watson < 4-DU" atau "1,7749 < 1,848<2,226". Dengan begitu bisa dikatakan tidak bergejala autokorelasi.

\section{Hasil Uji Heterokedastisitas}

Model regresi baik yaitu yang tidak bergejala heterokedastisitas, uji heterokedastisitas meliputi:

Tabel 7. Hasil Uji Heterokedastisitas Spearman's Rho

\begin{tabular}{lllr}
\hline & & & $\begin{array}{c}\text { Unstandardized } \\
\text { Residual }\end{array}$ \\
\hline Spearman's & & .098 \\
rho & Ukuran & Correlation Coefficient & .362 \\
& Perusahaan & Sig. (2-tailed) & 88 \\
& & N & -.077 \\
& Profitabilitas & Correlation Coefficient & .475 \\
& & Sig. (2-tailed) & 88 \\
& N & -.128 \\
& Struktur Modal & .234 \\
& & Correlation Coefficient & 88 \\
& & Cig. (2-tailed) & -.128 \\
& Leverage & Correlation Coefficient & .234 \\
& Sig. (2-tailed) & 88 \\
& Kepemilikan & Correlation Coefficient & -.042
\end{tabular}


Owner: Riset \& Jurnal Akuntansi

e-ISSN : 2548-9224 |p-ISSN : 2548-7507

Volume 6 Nomor 1, Januari 2022

DOI : https://doi.org/10.33395/owner.v6i1.580

\begin{tabular}{llr} 
Institusional & Sig. (2-tailed) & .695 \\
& $\mathrm{~N}$ & 88 \\
\multirow{2}{*}{ Unstandardized } & Correlation Coefficient & 1.000 \\
Residual & Sig. (2-tailed) & 88 \\
& $\mathrm{~N}$ &
\end{tabular}

Signifikansi ini dengan variabel firm size, profitabilitas, struktur modal, leverage \& kepemilikan institusional tidak terindikasi masalah heterokedastisitas.

\section{Hasil Analisis Regresi Linear Berganda}

Tabel 8. Analisis Regresi Linear Berganda

\begin{tabular}{|c|c|c|c|c|c|}
\hline \multirow[t]{2}{*}{ Model } & \multicolumn{2}{|c|}{$\begin{array}{l}\text { Unstandardized } \\
\text { Coefficients }\end{array}$} & \multirow{2}{*}{$\begin{array}{l}\text { Standardized } \\
\text { Coefficients } \\
\text { Beta }\end{array}$} & \multirow[t]{2}{*}{$\mathrm{t}$} & \multirow[t]{2}{*}{ Sig. } \\
\hline & B & Std. Error & & & \\
\hline (Constant) & 5726.747 & 1293.129 & & 4.429 & .000 \\
\hline Ukuran & -192.572 & 36.855 & -.345 & -5.225 & .000 \\
\hline Perusahaan & & & & & \\
\hline Profitabilitas & 7887.737 & 3196.859 & .154 & 2.467 & 016 \\
\hline Struktur Modal & 4239.911 & 369.084 & 1.666 & 11.488 & .000 \\
\hline Leverage & -11131.480 & 1464.386 & -1.236 & -7.601 & .000 \\
\hline Kepemilikan & -1256.843 & 741.432 & -.127 & -1.695 & .094 \\
\hline Institusional & & & & & \\
\hline
\end{tabular}

Hasil dari analisis regresi linear berganda ini dapat dihitung sebagai berikut:

$\mathrm{Y}=5,726.747-192.572 \mathrm{X} 1+7,887.737 \mathrm{X} 2+4,239.911 \mathrm{X} 3-11,131.480 \mathrm{X} 4-1,256.843 \mathrm{X} 5$

1. Nilai konstanta (nilai mutlak) sebesar 5,726.747 yaitu variabel independen (firm size), profitabilitas, struktur modal, leverage, \& kepemilikan institusional dianggap konstan sama dengan bernilai 0 maka nilai suatu perusahaan 5,726.747 dengan asumsi variabel lain tetap.

2. Nilai firm size sebesar -192.572 maka setiap ukuran perusahaan dinaikkan satu "satuan" maka nilai suatu perusahaan juga ikut menurun 192.572 dengan asumsi variabel lain tetap.

3. Nilai profitabilitas sebesar 7,887.737 maka setiap profitabilitas dinaikkan 1 "satuan" dengan begitu nilai suatu perusahaan juga ikut naik sebesar 7,887.737 dengan asumsi variabel lain tetap.

4. Nilai struktur modal sebesar 4,239.911 maka setiap struktur modal dinaikkan 1 "satuan" maka nilai suatu perusahaan juga ikut naik sebesar 4,239.911 dengan asumsi variabel lain tetap.

5. Nilai leverage sebesar -11,131.480 maka setiap leverage dinaikkan 1 "satuan" maka firm value juga ikut menurun sebesar 11,131.480 dengan asumsi variabel lain tetap.

6. Nilai kepemilikan institusional sebesar -1,256.843 maka setiap kepemilikan institusional dinaikkan satu "satuan" maka, firm value juga ikut menurun 1,256.843 dengan variabel lain tetap.

\section{Koefisien Determinasi}

\section{Tabel 9. Koefisien Determinasi Model Summary}

\begin{tabular}{rrrrr}
\hline & R & R Square & $\begin{array}{c}\text { Adjusted R } \\
\text { Square }\end{array}$ & $\begin{array}{l}\text { Std. Error of } \\
\text { the Estimate }\end{array}$ \\
\hline 1 & $.869^{\mathrm{a}}$ & .756 & .741 & 855.40387 \\
\hline
\end{tabular}


Berdasarakan tabel 8 dengan variasi variabel independen terlihat dari adjusted $\mathrm{R}$ square yakni 0,741 berarti $74,1 \%$ dengan variasi variabel nilai perusahaan (PBV) dapat diuraikan oleh variabel ukuran perusahaan (SIZE), profitabilitas (ROA), struktur modal (DER), Leverage (DAR) dan Kepemilikan Institusional (INST) yang mana sisanya 25,9\% yaitu variasi variabel lain yang tidak dimasukkan pada penelitian.

\section{Hasil Kelayakan}

Tabel 10. Hasil Uji F

ANOVA $^{\mathrm{a}}$

\begin{tabular}{llrrrrr}
\hline Model & & Sum of Squares & df & Mean Square & F & Sig. \\
\hline 1 & Regression & 185927939.726 & 5 & 37185587.945 & 50.820 & $.000^{\mathrm{b}}$ \\
& Residual & 60000693.906 & 82 & 731715.779 & & \\
& Total & 245928633.632 & 87 & & & \\
\end{tabular}

Dari Tabel 10 bahwa SIZE, ROA, DER, DAR \& INST mempengaruhi firm value properti \& real estate untuk tahun 2015-2019 yang bisa dilihat dari $\mathrm{F}$ hitung 50,820 $>2,483$. Sehingga menyimpulkan model 1 memenuhi kelayakan.

\section{Hasil Uji Hipotesis}

Tabel 11. Uji Hipotesis

\begin{tabular}{|c|c|c|c|c|c|c|}
\hline \multirow{2}{*}{\multicolumn{2}{|c|}{ Model }} & \multicolumn{2}{|c|}{$\begin{array}{l}\text { Unstandardized } \\
\text { Coefficients }\end{array}$} & \multirow{2}{*}{$\begin{array}{c}\text { Standardized } \\
\text { Coefficients } \\
\text { Beta } \\
\end{array}$} & \multirow[t]{2}{*}{$\mathrm{t}$} & \multirow[t]{2}{*}{ Sig. } \\
\hline & & $\mathrm{B}$ & Std. Error & & & \\
\hline \multirow[t]{6}{*}{1} & (Constant) & 5726.747 & 1293.129 & & 4.429 & .000 \\
\hline & Ukuran Perusahaan & -192.572 & 36.855 & -.345 & -5.225 & .000 \\
\hline & Profitabilitas & 7887.737 & 3196.859 & .154 & 2.467 & .016 \\
\hline & Struktur Modal & 4239.911 & 369.084 & 1.666 & 11.488 & .000 \\
\hline & Leverage & -11131.480 & 1464.386 & -1.236 & -7.601 & .000 \\
\hline & $\begin{array}{l}\text { Kepemilikan } \\
\text { Institusional }\end{array}$ & -1256.843 & 741.432 & -.127 & -1.695 & .094 \\
\hline
\end{tabular}

Berdasarkan tabel 11 pada uji t diambil dengan rumus $(\alpha / 2 ; \mathrm{n}-\mathrm{k}-1)=(0,05 / 2 ; 88-4-1)=$ 0,$025 ; 83$ maka t tabel nya adalah 1,989 diuraikan meliputi:

1) Hasil perhitungan pada firm size diperoleh thitung yaitu $-5,225 \& \mathrm{t}$ tabel yaitu $-1,989$ atau $\mathrm{t}$ hitung lebihdari t tabel $(-5,225>-1,989) \&$ sig. $0,000<0,05$ artinya firm size berpengaruh negatif \& signifikan pada firm value properti \& real estate di BEI tahun 20152019.

2) Hasil perhitungan pada profitability diperoleh t hitung sebesar $2,467 \& \mathrm{t}$ tabel yaitu 1,989 atau $t$ hitung lebih dari t tabel $(2,467>1,989) \&$ sig. $0,016<0,05$ artinya profitability berpengaruh positif \& signifikan pada firm value properti \& real estate di BEI 2015-2019.

3) Hasil perhitungan pada struktur modal diperoleh t hitung $11,488 \& \mathrm{t}$ tabelnya 1,989 atau $\mathrm{t}$ hitung lebihdari t tabel $(11,488>1,989)$ \& sig. $0,000<0,05$ artinya struktur modal berpengaruh positif $\&$ signifikan pada nilai perusahaan properti dan real estate di BEI tahun 2015-2019.

4) Hasil perhitungan pada leverage diperoleh thitung -7,601 dan t tabel -1,989 atau t hitung > t tabel $(-7,601>-1,989) \&$ sig. $0,000<0,05$ artinya leverage berpengaruh negatif \& signifikan pada firm value properti dan real estate di BEI 2015-2019.

5) Hasil perhitungan pada kepemilikan institusional diperoleh thitung -1,695 dan t-tabelnya 1,989 , t hitung yaitu kurangdari t tabelnya, $(-1,695<-1,989) \&$ sig. $0,094>0,05$ artinya kepemilikan institusional tidak berpengaruh signifikan pada firm value properti \& real estate di BEI 2015-2019. 


\section{Pengaruh firm size dan Nilai Perusahaan}

\section{PEMBAHASAN}

Hasil pengujian yaitu pada tabel 11 menunjukkan bahwa firm size berpengaruh negatif \& signifikan terhadap firm value properti \& real estate di BEI 2015-2019. Kemudian sejalan dengan Al-Slehat (2020) firm size mempunyai pengaruh terhadap nilai suatu perusahaan. Hal sama ditemukan Irawan \& Kusuma (2019) besar atau kecilnya firm size mempengaruhi terhadap nilai suatu perusahaan. Namun berbeda dengan Marhaeningtyas \& Hartono (2020) menunjukkan hasil perusahaan tidak perlu menambah jumlah aset untuk peningkatan nilai suatu perusahaan, oleh sebab itu investor akan menilai suatu perusahaan pada tinjauan secara keseluruhan mencakup perspektif dalam perusahaan meliputi tingkat penjualan \& laporan keuangan perusahaan.

Hasil dari peneliti firm size diukur menggunakan SIZE berpengaruh negatif dan signifikan terhadap nilai suatu perusahaan. Semakin besar ukuran perusahaan maka semakin kecil nilai suatu perusahaan (PBV). Sehingga dapat menurunkan minat investor terhadap nilai perusahaan di masa yang akan mendatang.

\section{Pengaruh ROA dan Nilai Perusahaan}

Pengujian yang seperti tersaji pada tabel 11 bahwa ROA memiliki pengaruh positif dan signifikan pada firm value properti \& real estate di BEI 2015-2019. Hal ini sejalan dengan Aggarwal \& Padhan (2017) profitability mempengaruhi kemampuan perusahaan hotel india dalam peningkatan nilai suatu perusahaan. Hal yang sama ditunjukkan oleh Siswanti \& Ngumar (2019) semakin baik kemajuan profitabilitas suatu perusahaan maka semakin baik pula peluang perusahaan di masa yang akan datang. Artinya nilai suatu perusahaan akan dinilai semakin baik oleh investor. Namun berbeda dengan Panjaitan et al., (2020) profitabilitas tidak memiliki pengaruh pada nilai suatu perusahaan.

Dari hasil penelitian ini bahwa profitabilitas diukur menggunakan ROA mempunyai pengaruh positif \& signifikan pada firm value. Perusahaan bisa menggunakan aktiva dengan efektif \& efisien maka dengan begitu perusahaan mendapat profit tinggi untuk peningkatan nilai suatu perusahaan. Sehingga, yang berarti profit suatu perusahaan stabil dari periode ke periode selanjutnya sehingga mampu menarik simpati pemegang saham untuk dapat menanam modalnya. Perusahaan dengan profitability yang melambung tinggi tercermin bahwa perusahaan dalam keadaan baik dan mempunyai peluang baik di masa yang akan datang. Sehingga investor atau pemegang saham lebih safety untuk berinvestasi pada perusahaan.

\section{Pengaruh DER dan Nilai Perusahaan}

Pengujian yang seperti tersaji pada tabel 11 DER berpengaruh positif dan signifikan pada firm value, perusahaan property \& real estate di BEI 2015-2019. Sejalan Fitrhi \& Asmeri (2020) perusahaan memiliki kemampuan untuk dapat menyeimbangkan manfaat \& biaya yang timbul dari penggunaan hutang (debt) maka akan berpengaruh dalam peningkatan nilai suatu perusahaan. Hal yang sama ditunjukkan Ayuba et al., (2019) capital structure mampu mempengaruhi pada nilai suatu perusahaan. Tidak sejalan dengan Febrianti \& Mufidah (2021) bahwa semakin high debt, oleh dari itu debt interset akan lebih tinggi pula. Artinya struktur modal suatu perusahaan dengan hutang yang banyak maka menyebabkan penurunan oleh harga saham sehingga dapat terjadi penurunan dari firm value.

Dari hasil penelitian ini menunjukkan capital structure diukur dengan DER yang memiliki pengaruh positive \& signifikan terhadap firm value. Perusahaan yang melakukan pendanaan hutang (debt financing) dalam jumlah sedikit maupun banyak tetap dapat meningkatkan nilai suatu perusahaan. Oleh sebab itu, perusahaan mampu membayar pinjaman \& beban bunga kepada pihak kreditur. Dengan demikian minat terhadap investor akan meningkat untuk dapat menanam modalnya pada perusahaan tersebut.

\section{Pengaruh Leverage (DAR) dan Nilai Perusahaan}

Hasil dari pengujian seperti tersaji tabel 11 bahwa leverage (DAR) berpengaruh negative dan signifikan pada firm value properti \& real estate di BEI 2015-2019. Penelitian ini dapat dikatakan sejalan dengan penelitian Dutta et al., (2018) leverage berpengaruh terhadap firm value. Sama halnya leverage berpengaruh pada firm value ditemukan (Widiyati, 
2020). Namun berbeda bahwa leverage tidak berpengaruh pada firm value (Lani \& Sufiyati, 2019).

Hasil penelitian ini mengatakan leverage diukur menggunakan DAR berpengaruh negatif dan signifikan terhadap firm value. Maka semakin tinggi DAR maka semakin rendah pula firm value. Dengan begitu perusahaan yang memiliki high debt cenderung beresiko untuk mengembalikan biaya hutangnya, maka dapat menurunkan minat pemegang saham terhadap firm value mendatang.

\section{Pengaruh Ownership Institusional (INST) dan Nilai Perusahaan}

Pengujian seperti tabel 11 yakni institutional ownership (INST) tidak berpengaruh dan tidak signifikan pada firm value property \& real estate di BEI 2015-2019. Sejalan dengan Israel et al., (2018) institutional ownership tidak berpengaruh terhadap firm value, dikarenakan perusahaan yang pengaruhi oleh pihak-pihak, meliputi campur tangan pemerintah. Tidak sejalan Oyedokun et al., (2020) institutional ownership mampu berpengaruh pada nilai suatu perusahaan. Hasil yang sama ditemukan oleh Aliyah \& Hermanto (2020) institutional ownership mempunyai pengaruh terhadap nilai perusahaan, dapat dilihat dari pihak institusionalnya mayoritas adalah para pemegang saham.

Hasil dari penelitian ini menunjukkan kepemilikan institusional (institutional ownership) diukur dengan INST tidak berpengaruh \& tidak signifikan pada firm value. Penyebabnya ialah kurangnya keikutsertaan pemilik saham institusi dalam pengambilan keputusan manajer sehingga mengakibatkan INST tidak berpengaruh pada firm value. Maka menurunkan minat investor pada firm value.

\section{KESIMPULAN}

Dari hasil peneliti ini \& analisis tentang pengaruh (SIZE), profitabilitas (ROA), struktur modal (DER), leverage (DAR) dan kepemilikan instutisonal (INST) pada nilai suatu perusahaan property \& real estate di BEI 2015-2019 dengan sampel sebanyak 20 maka bisa diambil kesimpulan dalam parsial SIZE, ROA, DER, \& DAR berpengaruh pada firm value properti \& real estate di BEI 2015-2019. Sedangkan kepemilikan institusional (INST) tidak mempunyai pengaruh pada firm value, properti \& real estate di BEI 2015-2019. Bagi para investor agar mempertimbangkan dalam mengambil keputusan investasi di perusahaan properti dan real estate dengan melihat firm size, profitabilitas, struktur modal, leverage \& institutional ownership yang dijalankan perusahaan, karena nilai suatu perusahaan yg baik adalah yang peluangnya baik di masa akan datang maka, dapat menyejahterakan investor. Untuk perusahaan sendiri dapat memberi saran mengenai tingkat nilai perusahaan yang dipengaruhi oleh (SIZE), profitabilitas (ROA), (DER), leverage (DAR) \& (INST). Hal ini menjadikan sebuah bahan pertimbangan evaluasi dan perbaikan yang dapat dilakukan perusahaan untuk terus meningkatkan firm value. Dalam penelitian ini nilai suatu perusahaan diukur dengan PBV, sehingga untuk penelitian dikemudian hari dapat mengukur dengan Tobin's $Q$, PER, DPR. Penelitian yang akan datang diharap agar menambahkan variabel-variabel penelitian seperti likuiditas, kebijakan deviden, pertumbuhan laba, kepemilikan manajerial (KM), dewan komisaris \& komite audit serta diharapkan untuk menambah sampel penelitian tidak hanya property \& real estate company di BEI 2015-2019, tetapi menggunakan perusahaan yang berbeda dan menambah tahun penelitian untuk memperluas pengujian.

\section{REFERENSI}

Aggarwal, D., \& Padhan, P. C. (2017). Impact Of Capital Structure On Firm Value : Evidence From Indian Hospitality Industry. Theoretical Economics Letters, 7(4), 982-1000. Https://Doi.Org/10.4236/Tel.2017.74067

Al-Slehat, Z. A. F. (2020). Impact Of Financial Leverage, Size And Assets Structure On Firm Value : Evidence From Industrial Sector, Jordan. International Business Research, 13(1), 109-120. Https://Doi.Org/10.5539/Ibr.V13n1p109

Aliyah, B. J., \& Hermanto, S. B. (2020). Pengaruh Profitabilitas, Ukuran Perusahaan, 
Kepemilikan Manajerial, Kepemilikan Institusional Terhadap Nilai Perusahaan. Jurnal Ilmu Dan Riset Akuntansi, 9(11), 2-23.

Astakoni, I. M. P., \& Wardita, I. W. (2020). Keputusan Investasi, Leverage, Profitabilitas, Dan Ukuran Perusahaan Sebagai Faktor Penentu Nilai Perusahaan Manufaktur. Jurnal Ekonomi, Bisnis Dan Akuntansi, 19(1), 10-23.

Ayuba, H., Ibrahim, M. A., \& Sulaiman, S. A. (2019). Effects Of Financial Performance, Capital Structure And Firm Size On Firms ' Value Of Insurance Companies In Nigeria. Journal Of Finance, Accounting And Management, 10(1), 57-74.

Brigham, E. F., \& Houston, J. F. (2011). Dasar-Dasar Manajemen Keuangan (Edisi Sebe). Salemba Empat.

Dewi, J. P., \& Damayanti, E. (2019). Analisis Pengaruh Struktur Modal, Profitabilitas, Dan Ukuran Perusahaan Terhadap Nilai Perusahaan Manufaktur Sektor Industri Makanan Dan Minuman Tahun 2013-2017. Jurnal Akuntansi Dan Bisnis Krisnadwipayana, 6(3), 71-78.

Dutta, S. R., Mukherjee, T., \& Sen, S. S. (2018). Impact Of Financial Leverage On The Value Of Firm: Evidence From Some Nse Listed Companies. The Besc Journal Of Commerce And Management, 4, 43-52.

Dwita, R., \& Kurniawan. (2019). Pengaruh Struktur Modal, Ukuran Perusahaan Dan Keputusan Investasi Terhadap Nilai Perusahaan. Statera: Jurnal Akuntansi Dan Keuangan, 1(1), 7690. Https://Doi.Org/10.33510/Statera.2019.1.1.76-89

Febrianti, I., \& Mufidah. (2021). Pengaruh Likuiditas, Struktur Modal, Dan Profitabilitas Terhadap Nilai Perusahaan Pada Industri Sub Sektor Farmasi Yang Terdaftar Di Bursa Efek Indonesia Tahun 2015 - 2019. Jurnal Ilmiah Universitas Batanghari Jambi, 21(2), 865-870. Https://Doi.Org/10.33087/Jiubj.V21i2.1574

Fitrhi, Y., \& Asmeri, R. (2020). Pengaruh Kepemilikan Manajerial, Struktur Modal Dan Ukuran Perusahaan Terhadap Nilai Perusahaan Pada Perusahaan Property Dan Real Estate Yang Terdaftar Di Bursa Efek Indonesia (Bei) Periode 2014-2016. Jurnal Matua, 2(3), 41-60.

Irawan, D., \& Kusuma, N. (2019). Pengaruh Struktur Modal Dan Ukuran Perusahaan. Jurnal Aktual Stie Trisna Negara, 17(1), 66-81.

Israel, C., Mangantar, M., \& Saerang, I. S. (2018). Pengaruh Struktur Modal, Kepemilikan Institusional Dan Ukuran Perusahaan Terhadap Nilai Perusahaan Pada Perusahaan Pertambangan Yang Terdaftar Di Bei. Jurnal Emba, 6(3), 1118-1127.

Lani, \& Sufiyati. (2019). Pengaruh Ukuran Perusahaan, Profitabilitas, Leverage, Dan Kepemilikan Institusional Perusahaan Terhadap Nilai Perusahaan. Jurnal Multiparadigma Akuntansi, I(3), 798-807.

Marhaeningtyas, D., \& Hartono, U. (2020). Kepemilikan Manajerial, Kebijakan Dividen, Leverage, Profitabilitas, Ukuran Perusahaan, Dan Nilai Perusahaan (Studi Pada Perusahaan Pertambangan Di Indonesia). Jurnal Ilmu Manajemen, 8(3), 1060-1072.

Nursanita, Faruqi, F., \& Rahayu, S. (2019). Pengaruh Kepemilikan Manajerial, Kepemilikan Institusional, Struktur Modal, Pertumbuhan Perusahaan Dan Profitabilitas Terhadap Nilai Perusahaan Pada Perusahaan Manufaktur Di Indonesia Tahun 2015-2018. Jurnal Stei Ekonomi, 28(01), 153-171.

Oyedokun, G. E., Isah, S., \& Awotomilusi, N. S. (2020). Ownership Structure And Firm Value Of Quoted Consumers Goods Firms In Nigeria. Journal Of Accounting And Strategic Finance, 3(2), 214-228. 
Panjaitan, P., Amanda, S., \& Liviani, C. (2020). Pengaruh Likuiditas, Leverage Dan Profitabilitas Terhadap Nilai Perusahaan Pada Sektor Barang Dan Konsumsi Yang Terdaftar Di Bursa Efek Indonesia Periode 2015-2018. Jurnal Ilmiah Universitas Batanghari Jambi, 20(3), 908-914. Https://Doi.Org/10.33087/Jiubj.V20i3.1073

Permatasari, N. I., \& Khuzaini. (2018). Pengaruh Ukuran Perusahaan, Struktur Modal, Dan Kepemilikan Institusional Terhadap Nilai Perusahaan Property And Real Estate. Jurnal Ilmu Dan Riset Manajemen, 7(3), 2-19.

Siswanti, D. E., \& Ngumar, S. (2019). Pengaruh Struktur Modal, Profitabilitas, Ukuran Perusahaan Terhadap Nilai Perusahaan. Jurnal Ilmu Dan Riset Akuntansi, 8(2), 2-20.

Tubagus, S. A. M., \& Khuzaini. (2020). Pengaruh Ukuran Perusahaan, Struktur Modal, Dan Kepemilikan Institusional Terhadap Nilai Perusahaan. Jurnal Ilmu Dan Riset Manajemen, 9(5), 2-21.

Widiyati, D. (2020). Pengaruh Profitabilitas, Ukuran Perusahaan, Leverage Dan Cash On Hand Terhadap Nilai Perusahaan (Studi Empiris Pada Perusahaan Pertambangan Batu Bara Yang Go Public Tahun 2017-2018 Di Bursa Efek Indonesia). Jurnal Riset Akuntansi, 15(2), 279-289.

Zahiroh, N., \& Prijati. (2018). Pengaruh Ukuran Perusahaan, Struktur Modal, Leverage,Dan Profitabilitas Terhadap Nilai Perusahaan. Jurnal Ilmu Dan Riset Manajemen :, 7(8), 1-19. 